\title{
Quantitative analysis of growth in coffee plants cultivated with a water-retaining polymer in an irrigated system ${ }^{1}$
}

\author{
Análise quantitativa do crescimento de cafeeiros cultivados com polímero hidro \\ retentor em sistema irrigado
}

\author{
Antonio Jackson de Jesus Souza ${ }^{2 *}$, Rubens José Guimarães ${ }^{2}$, Alberto Colombo ${ }^{3}$, José Antonio do Vale Sant'Ana ${ }^{3}$ \\ e Dalyse Toledo Castanheira ${ }^{2}$
}

\begin{abstract}
This study aimed to evaluate the use of hydro polymer retainer in the quantitative growth of coffee plants at different levels of irrigation and soil types. The experiment was conducted in pots with seedlings bag in the greenhouse of the Setor de Cafeicultura, Universidade Federal de Lavras. The experimental design was in randomized blocks in factorial $(2 \times 4 \times 2)$ : absence or presence of hydro polymer retainer, four levels of irrigation $(25 \%, 50 \%, 75 \%$ and $100 \%$ ), two soil types (sandy soil and medium texture). At 150 days evaluated the stem diameter, plant height, leaf area, number of leaves, dry weight of shoots, plant dry mass, root dry weight, root dry weight ratio of shoot, leaf area ratio, absolute growth rate, relative growth rate, net assimilation rate and leaf area index. It was concluded that the polymer hydro retainer hydrated favored the growth of coffee plants and irrigation promoted greater growth of coffee in medium textured soil compared to soils with sandy texture.
\end{abstract}

Key words: Soil types. Greenhouse. Coffea arabica L.. Hydrogel.

RESUMO - Objetivou-se avaliar o uso do polímero hidro retentor no crescimento quantitativo de cafeeiros em diferentes níveis de irrigação e tipos de solo. O experimento foi instalado em vasos com mudas produzidas em saquinhos, em casa de vegetação no Setor de Cafeicultura, Universidade Federal de Lavras, MG. O experimento foi conduzido em delineamento de blocos ao acaso em esquema fatorial $(2 \times 4 \times 2)$ : ausência ou presença do polímero hidro retentor, quatro níveis de irrigação $(25 \%, 50 \%, 75 \%$ e $100 \%)$, dois tipos de solo (solo com textura média e arenosa). Aos 150 dias, avaliou-se o diâmetro de caule, altura de planta, área foliar, número de folhas, massa seca de parte aérea, massa seca de plantas, massa seca de raízes, relação massa seca de raiz e parte aérea, razão de área foliar, taxa de crescimento absoluto, taxa de crescimento relativo, taxa de assimilação líquida e índice de área foliar. Concluiu-se que o polímero hidro retentor hidratado favoreceu o crescimento de plantas de café e que a irrigação promoveu maior crescimento do cafeeiro em solo de textura média, quando comparado a solos de textura arenosa.

Palavras-chave: Tipos de solo. Casa de vegetação. Coffea arabica L.. Hidrogel.

\footnotetext{
DOI: $10.5935 / 1806-6690.20160019$

* Autor para correspondência

${ }^{1}$ Recebido para publicação em 17/04/2014; aprovado em 20/10/2015

Parte da Tese de Doutorado do primeiro autor, apresentada ao Programa de Pós-Graduação em Agronomia / Fitotecnia da Universidade Federal Lavras/UFLA

${ }^{2}$ Departamento de Agricultura/DAG - Setor de Cafeicultura, Universidade Federal de Lavras/UFLA, Caixa Postal 3037, Lavras-MG, Brasil, 37.200-000,jacksonagro@gmail.com, rubensjg@dag.ufla.br, dalysecastanheira@hotmail.com

32 Departamento de Engenharia/DEG - Hidráulica, Universidade Federal de Lavras/UFLA, Caixa Postal 3037, Lavras-MG, Brasil, 37.200-000, acolombo@deg.ufla.br, zinhojaves@yahoo.com.br
} 


\section{INTRODUCTION}

Phytomass production in a coffee plant is the result of the plant interacting with the environment. The quantitative analysis of plant growth is considered to be the standard method for estimating the primary productivity of plants. The quantitative evaluation of growth is of fundamental importance, due to there being a high positive correlation of vegetative characteristics with initial productivity in the coffee plant (CARVALHO et al., 2010).

Among the estimates in a quantitative analysis of plant growth, it is possible to determine: the "absolute growth rate" as being the increase in plant phytomass in any one period; the "relative growth rate" as representing the amount of plant material produced by a given amount of existing material (g) over a time interval (days); and the "net assimilation rate" as an assessment of the size of the assimilating system (leaf), which is involved in the production of dry matter. That is, these characteristics estimate net photosynthesis, representing the balance between any material produced and any losses due to respiration (CAIRO; OLIVEIRA; MESQUITA, 2008).

Interpretation of the results of quantitative growth analysis should take into account many other variables such as soil and air moisture and consequently, the plant water balance, since growth in coffee plants varies with the availability of water.

A reflection of climate change has been seen in the major coffee-producing regions, such as the South of Minas Gerais in January 2014, with rainfall below the historical average. One alternative way to minimise this problem may be the use of a water-retaining polymer that makes water available for longer periods of time in the soil. This product (polyacrylamide polymer) when hydrated, has a gelatinous characteristic, and can provide water over a longer period, regulating the supply of water to the plants (ZONTA et al., 2009).

The texture of the soil may interfere with the efficiency of these polymers, since soils have different characteristics of porosity and CEC, among others. There is scant information in the literature on the effects of a water-retaining polymer on plants in various types of soil, especially as to the use of the polymer in irrigated systems. The aim of this work was to analyse the quantitative growth of coffee plants cultivated with the use of a waterretaining polymer in an irrigated system, and on soils of a medium and sandy texture, under greenhouse conditions.

\section{MATERIAL AND METHODS}

An experiment was conducted at the Sector for Coffee Cultivation of the Department of Agriculture at the Federal University of Lavras (UFLA), in Lavras, in the State of Minas Gerais (MG), Brazil, located at $21^{\circ} 15^{\prime}$ $\mathrm{S}$ and $45^{\circ} 00^{\prime} \mathrm{W}$, and at an average altitude of $918 \mathrm{~m}$ (DANTAS; CARVALHO, FERREIRA, 2007).

The seedlings used in the experiment were produced on site, in polyethylene bags filled with standard substrate $(300 \mathrm{~L}$ of manure, $700 \mathrm{~L}$ of soil and $5 \mathrm{~kg}$ of single super phosphate), using beans of the Acaiá Cerrado MG 1474 cultivar of arabica coffee. Upon displaying three pairs of leaves, the seedlings were planted into $20 \mathrm{~L}$ pots, which were arranged on benches $0.8 \mathrm{~m}$ above the ground, at a spacing of $0.70 \mathrm{x}$ $0.60 \mathrm{~m}$. The soils were classified as a typic spodic Orthic Quartzarenic Neosol (RQo), and a typic dystrophic RedYellow Latosol (LVAd) (Table 1), employing the Brazilian system of soil classification (SANTOS, 2013).

Table 1 - Physical and chemical analysis of the soils used in the experiment

\begin{tabular}{|c|c|c|c|c|c|c|c|c|c|c|c|c|}
\hline SOIL & Clay & $\mathrm{pH}$ & $\mathrm{P}$ & $\mathrm{K}$ & $\mathrm{Na}$ & $\mathrm{Ca}$ & $\mathrm{Mg}$ & $\mathrm{Al}$ & $\mathrm{H}+\mathrm{Al}$ & SB & (t) & (T) \\
\hline Class & dag kg-1 & $\left(\mathrm{H}_{2} \mathrm{O}\right)$ & \multicolumn{3}{|c|}{ 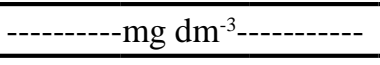 } & ------ & ----cmo & $\mathrm{Im}^{-3}-$ & --------- & \multicolumn{3}{|c|}{-----cmol $\mathrm{dm}^{-3}-\mathrm{c}_{\mathrm{c}}$} \\
\hline RQo* & 5 & 5.2 & 7.9 & 67 & - & 0.2 & 0.1 & 0.6 & 4.5 & 0.4 & 1 & 5 \\
\hline $\begin{array}{c}\text { LVAd }{ }^{* *} \\
\text { (Continued) }\end{array}$ & 26 & 5.3 & 0.6 & 39 & - & 0.1 & 0.1 & 0.1 & 2.9 & 0.3 & 0.4 & 3.2 \\
\hline SOIL & \multicolumn{2}{|c|}{$\mathrm{V}$} & \multicolumn{2}{|c|}{$\mathrm{M}$} & \multicolumn{2}{|c|}{ MO } & Prem & $\mathrm{Zn}$ & $\mathrm{Mn}$ & $\mathrm{Cu}$ & B & $S$ \\
\hline Class & \multicolumn{4}{|c|}{----------------------\%"--------------------- } & \multicolumn{2}{|c|}{ dag kg-1 } & $\mathrm{mg} \mathrm{L}^{-1}$ & \multicolumn{5}{|c|}{----------------'mg dm³'-------------------- } \\
\hline Rqo & \multicolumn{2}{|c|}{9} & \multicolumn{2}{|c|}{57.5} & \multicolumn{2}{|c|}{1.6} & 38.3 & 0.5 & 3.0 & 0.4 & 0.1 & 6.7 \\
\hline LVAd & \multicolumn{2}{|c|}{8.8} & \multicolumn{2}{|c|}{26.3} & \multicolumn{2}{|c|}{0.6} & 16.4 & 0.2 & 1.2 & 0.3 & 0.1 & 7.5 \\
\hline
\end{tabular}


Soil correction was carried out by increasing base saturation to $60 \%$, using dolomitic limestone with a PRNT of $87 \%$ mixed with the moist soil, which was piled up and covered with a tarpaulin for 26 days to allow for reaction. The use of fertilizer was as recommended for pots (FAQUIN; VALE; FURTINI NETO, 2008).

In the treatments employing the water-retaining polymer, preparation of the polymer solution was in the ratio of $1.5 \mathrm{~kg}$ of water-retaining polymer to 400 litres of water, with 1.5 litres of the solution being applied when planting the seedlings in the pots, adapting the recommendations of Pieve et al. (2013).

In the pots with no polymer (the reference for setting the water levels) undisturbed soil samples were collected using a Uhland cylinder to determine the humidity $\left(\mathrm{g} \mathrm{g}^{-1}\right)$, matric potential $(\mathrm{kPa})$ and the soil-water characteristic curve. With this information, a spreadsheet was created to determine the amount of water to be applied for each irrigation treatment. Irrigation was carried out on Mondays and Thursdays, with manual application of the volume of water corresponding to each treatment measured by means of a graduated test tube.

The experiment used a $2 \times 4 \times 2$ factorial scheme: with and without use of the water-retaining polymer, four irrigation levels $(25 \%, 50 \%, 75 \%$ and $100 \%$ of the calculated irrigation level), and two soil types (medium and sandy texture). The statistical design was of randomised blocks with three replications, giving 48 experimental lots, with each pot being one experimental lot. Evaluations were made at planting and after 150 days. The following non-destructive variables were determined: stem diameter (SD) in mm, using a digital caliper, at plant collection; plant height $(\mathrm{PH})$ in $\mathrm{cm}$, using a graduated rule, from the base to the apical meristem; leaf area (LA) in $\mathrm{cm}^{2}$, measured using a graduated scale (multiplying the greatest length by the greatest width of the leaves of each pair and multiplying by the constant 0.667 , then multiplying by two, and finally summing the leaf area obtained for each pair to get the total leaf area of the plant); number of leaves (NL), determined by counting any true leaves greater than $2.5 \mathrm{~cm}$ in length.

At planting, destructive evaluations were made in 48 plants (samples taken in the nursery) so as to ensure plant uniformity (no significant differences), and again at the end of the experiment. The plants were cut near the base, separated into shoots and roots, which were rinsed under running and distilled water, and then placed into paper bags to dry in a forced air circulation oven at 65 ${ }^{\circ} \mathrm{C}$ to constant weight. After drying, the weight of each sample was determined on a precision scale, giving the shoot dry weight (SDW), root dry weight (RDW) and by summing the two, the dry weight of the plant (PDW) in grams $(\mathrm{g})$.

Quantitative analysis of plant growth used the parameters: root dry weight/shoot dry weight ratio (RDW $\mathrm{SH}^{-1}$ ), leaf area ratio (LAR), absolute growth rate (AGR), relative growth rate (RGR), net assimilation rate (NAR), and leaf area index (LAI).

As recommended by Cairo; Oliveira and Mesquita (2008), the following formulas were used:

$R D W P A^{1}=R D W / S D W$ (considering the ratio of root dry mass (g) to shoot dry mass in grams).

$L A R=L A f / P D W f\left(\right.$ expressed in $\left.\mathrm{cm}^{2} \mathrm{~g}^{-1}\right)$, where LAf e PDWf are leaf area and plant dry weight respectively.

$A G R=(P D W f-P D W i) /(t f-t i)\left(\right.$ expressed in $\left.\mathrm{g} \mathrm{day}^{-1}\right)$, where PDWf and PDWi are the plant dry weight at the start and the end of the experiment, tf and ti correspond to the final and initial period of the experiment in days.

$R G R=(\ln P D W f-\ln P D W i) /(t f-t i)\left(\right.$ expressed in $\left.\mathrm{g} \mathrm{g}^{-1} \mathrm{day}^{-1}\right)$, where lnPDWf and lnPDWi are the natural logarithms for plant dry weight at the start and end, (ti e tf correspond to the period in days).

$N A R=[(P D W f-P D W i) /(L A f-L A i)] *[(\ln L A f-\ln L A i) /$ $(t f-t i)]$, defined as the ratio expressed by the difference between the final and initial dry weight (PDWf and PDWi) and initial and final leaf area (AFf and AFi), as well as the ratio of the natural logarithm of the initial to final leaf area (lnLAf and $\operatorname{lnLAi}$ ) and of the period (tf - ti), with data expressed in $\mathrm{g} \mathrm{cm}^{-2} \mathrm{day}^{-1}$.

$L A I=R G R *(L A / P D W f)$ is a dimensionless variable, where RGR is the relative growth rate, LA and PDWf are the leaf area and plant dry weight at the end of the experiment (150 days after the start of the experiment).

The collected data were tabulated, and tests for normality and homogeneity performed. Variance analysis was carried out with the help of the SISVAR ${ }^{\circledR}$ statistical analysis software (FERREIRA, 2011). When significant, interactions for the irrigation levels and the use or not of water-retaining polymer in each type of seedling were broken down by studying the regression.

\section{RESULTS AND DISCUSSION}

No significance was found for the triple interaction between polymer, irrigation level and soil type (G x I x S). There was only a significant interaction between irrigation level and soil type (I x S) (Tables 2 and 3). 
Table 2 - Summary of the variance analysis for the variables stem diameter (SD mm), plant height (PH, $\mathrm{cm})$, leaf area $\left(\mathrm{LA}, \mathrm{cm}^{2}\right)$, number of leaves (NL), shoot dry weight (SDW, g) and plant dry weight (PDW, g), for source of variation (SV), water-retaining polymer (G), soil type (S) and irrigation level (I), at 150 days after start of the experiment

\begin{tabular}{lccccccc}
\hline \multirow{2}{*}{ SV } & \multirow{2}{*}{ GL } & \multicolumn{7}{c}{ Mean Square } \\
\cline { 2 - 7 } & & SD & PH & LA & NL & SDW & SDP \\
\hline G & 1 & 1.110 & $52.501^{*}$ & 48096.565 & 30.083 & $14.666^{*}$ & $26.150^{*}$ \\
S & 1 & $8.085^{* *}$ & $164.280^{* *}$ & $109143.067^{*}$ & 52.083 & $49.329^{* *}$ & $89.480^{* *}$ \\
$\mathrm{I}$ & 3 & $5.121^{* *}$ & $577.002^{* *}$ & $567649.742^{* *}$ & $505.722^{* *}$ & $78.990^{* *}$ & $113.022^{* *}$ \\
$\mathrm{~B}$ & 2 & 0.623 & $51.193^{* *}$ & $136568.394^{* *}$ & $209.896^{* *}$ & $44.798^{* *}$ & $72.967^{* *}$ \\
GXS & 1 & 0.001 & 1.141 & 317.387 & $1.7 .10^{-15}$ & 0.005 & 0.209 \\
GxI & 3 & 0.035 & 0.314 & 5979.623 & 32.139 & 0.617 & 1.858 \\
IxS & 3 & $1.675^{* *}$ & $26.124^{*}$ & 24912.700 & 40.139 & $9.855^{*}$ & $13.468 \#$ \\
GxIxS & 3 & 0.409 & 6.585 & 13541.764 & 13.500 & 2.117 & 4.332 \\
Error & 30 & 0.273 & 8.784 & 17629.793 & 21.607 & 3.085 & 4.869 \\
CV \% & & 11.15 & 8.88 & 22.22 & 24.04 & 24.92 & 25.52 \\
\hline
\end{tabular}

* Significant by F-test at $5 \%$ probability; ** Significant by F-test at $1 \%$ probability; \# Significant by F-test at $5.9 \%$ probability

Table 3 - Summary of the variance analysis for the variables root dry weight (RDW, g) root dry weight to shoot dry weight ratio (RDW $\mathrm{SH}^{-1}$ ), leaf area ratio (LAR, $\mathrm{cm}^{2} \mathrm{~g}^{-1}$ ) absolute growth rate (AGR, $\mathrm{g} \mathrm{day}^{-1}$ ), relative growth rate $\left(\mathrm{RGR}, \mathrm{g} \mathrm{g}^{-1} \mathrm{day}^{-1}\right.$ ), net assimilation rate (NAR, $\mathrm{g} \mathrm{cm}^{2} \mathrm{da}^{-1}$ ) and leaf area index (LAI), for source of variation (SV), water-retaining polymer (G), soil type (S) and irrigation level (I), at 150 days after start of the experiment

\begin{tabular}{lcccccccc}
\hline \multirow{2}{*}{ SV } & \multirow{2}{*}{ GL } & \multicolumn{8}{c}{ Mean Square } \\
\cline { 3 - 9 } & & RDW & RDW SH $^{-1}$ & LAR & AGR & RGR & NAR & LAI \\
\hline G & 1 & 1.649 & 0.002 & 143.821 & $0.002^{*}$ & $0.3 .10^{-5 * *}$ & $6.3 .10^{-9}$ & 0.026 \\
S & 1 & $5.933^{* *}$ & $0.032^{* *}$ & $1647.544^{* *}$ & $0.006^{* * *}$ & $0.6 .10^{-5 * *}$ & $3.5 .10^{-8 * *}$ & 0.075 \\
I & 3 & $3.660^{* *}$ & $0.019^{* *}$ & $419.952^{* *}$ & $0.007^{* * *}$ & $0.1 .10^{-4 * *}$ & $2.2 .10^{-8 * *}$ & $0.590^{* *}$ \\
B & 2 & $4.425^{* *}$ & $0.026^{* *}$ & $587.064^{* *}$ & $0.004^{* *}$ & $0.2 .10^{-5 * *}$ & $1.7 .10^{-8 * *}$ & 0.042 \\
GxS & 1 & 0.150 & $0.4 .10^{-4}$ & 5.002 & $0.1 .10^{-5}$ & $4.3 .10^{-7}$ & $5.2 .10-11$ & 0.001 \\
GxI & 3 & 0.35 & 0.004 & 44.290 & $0.1 .10^{-4}$ & $7.13 .10^{-7}$ & $3.8 .10-10$ & 0.037 \\
IxS & 3 & 0.355 & 0.002 & 159.372 & $0.001 \#$ & $0.1 .10^{-5}$ & $4.8 .10-9$ & 0.021 \\
GxIxS & 3 & 0.662 & 0.007 & 142.267 & $0.3 .10^{-4}$ & $0.1 .10^{-5}$ & $1.4 .10-9$ & 0.088 \\
Error & 30 & 0.428 & 0.004 & 90.796 & $0.3 .10^{-4}$ & $0.1 .10^{-5}$ & $1.8 .10-9$ & 0.042 \\
CV \% & & 40.87 & 28.27 & 13.17 & 27.23 & 10.05 & 17.41 & 14.10 \\
\hline
\end{tabular}

* Significant by F-test at $5 \%$ probability; ** Significant by F-test at 1\% probability; \# Significant by F-test at 5.8\% probability

The irrigation level influenced growth in the coffee plants in different ways, by varying the type of soil (medium and sandy), with the interaction I x S being significant for the characteristics stem diameter (SD), plant height $(\mathrm{PH})$, shoot dry matter (SDM), plant dry matter plant (PDW) and absolute growth rate (AGR) (Tables 2 and 3).

By breaking down the interaction of the irrigation level with soil type (I x S), an increase was seen in SD and
PH with an increase in the irrigation level to $100 \%$ (Figure 1). At 150 days there was an effect from irrigation on the medium-texture soil only on the SD of the coffee plants. At the $100 \%$ irrigation level, a stem diameter of $6.07 \mathrm{~mm}$ was found, i.e. $61 \%$ greater than the diameter of $3.73 \mathrm{~mm}$ seen at the level of 25\% (Figure 1). Determination of stem diameter is very important in biometric evaluations as it is an indicator of the net assimilation rates of the products of photosynthesis. Almeida et al. (2005) observed that 
Figure 1 - Stem diameter $(\mathrm{mm})$ and plant height $(\mathrm{cm})$ in the Acaiá Cerrado MG-1474 cultivar of arabica coffee, for irrigation level, in soils with a medium (SM) and sandy (AR) texture
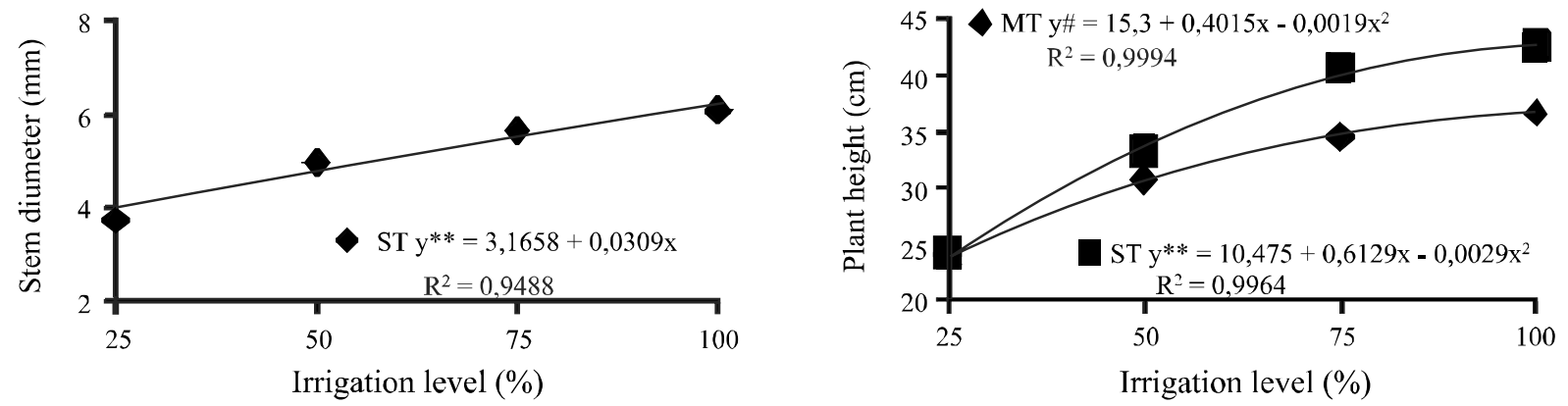

${ }^{* *}$ Significant difference by F-test at $1 \%$ probability; \# Significant difference by F-test at $6 \%$ probability

stem diameter determines a higher survival rate for coffee seedlings in the field.

With $\mathrm{PH}$, an effect was found from irrigation for the two types of soil being tested. The greatest difference between the types of soil was found at the irrigation level of $100 \%$, with a superior plant response to the irrigation level in the soil of medium texture, where the plants displayed $42.6 \mathrm{~cm}$ instead of the 36.6 in sandy soil (Figure 1), i.e. $16 \%$ greater. Whereas in a situation of water deficit with only a $25 \%$ level of irrigation, the smallest PH, of only $24.1 \mathrm{~cm}$, was found for both types of soil. Clemente et al. (2008), evaluating stem diameter and height in coffee plants at 90 days after planting in pots, found values of $9.7 \mathrm{~mm}$ for stem diameter and 56 $\mathrm{cm}$ for plant height. These differences are due to the seedlings used by these authors presenting six pairs of leaves, while in the present work, the seedlings only displayed three pairs of leaves.

The difference in PH seen for the two types of soil is due to the specific characteristic of each soil. Texture is crucial for the retention of water, as it acts directly on the areas of contact between the solid particles and the water
(GOMES et al., 2004). Those researchers, evaluating physical, chemical and mineralogical attributes, saw there was a positive correlation between water retention and the clay content of the soil. Thus, the greater plant height seen in soil of a medium texture, is due to the greater storage and availability of water in that type of soil compared to sandy soil.

Evaluation of shoot dry weight (SDW) and plant dry weight (PDW) is of primary importance when quantifying the accumulation of biomass (FONTES; DIAS; SILVA, 2005). Upon breaking down the interaction between irrigation level and type of soil (I x S), it was found that increasing the level of irrigation to $100 \%$ favoured SDW and PDW to the maximum (Figure 2). Oliveira et al. (2004), working with different irrigation levels for coffee plants in pots, found that irrigation at $100 \%$ produced greater plant growth. These authors also found that irrigation levels when reduced by $20 \%$ and $40 \%$ led to the smallest values, producing less growth in the coffee plants. Similar behaviour to conditions of water stress was also seen in the present work, when applying a level of $25 \%$ (Figure 2).

Figure 2 - Shoot dry weight (g) and plant dry weight (g) in the Acaiá Cerrado MG-1474 cultivar of arabica coffee, for irrigation level, in soils with a medium (MT) and sandy (ST) texture
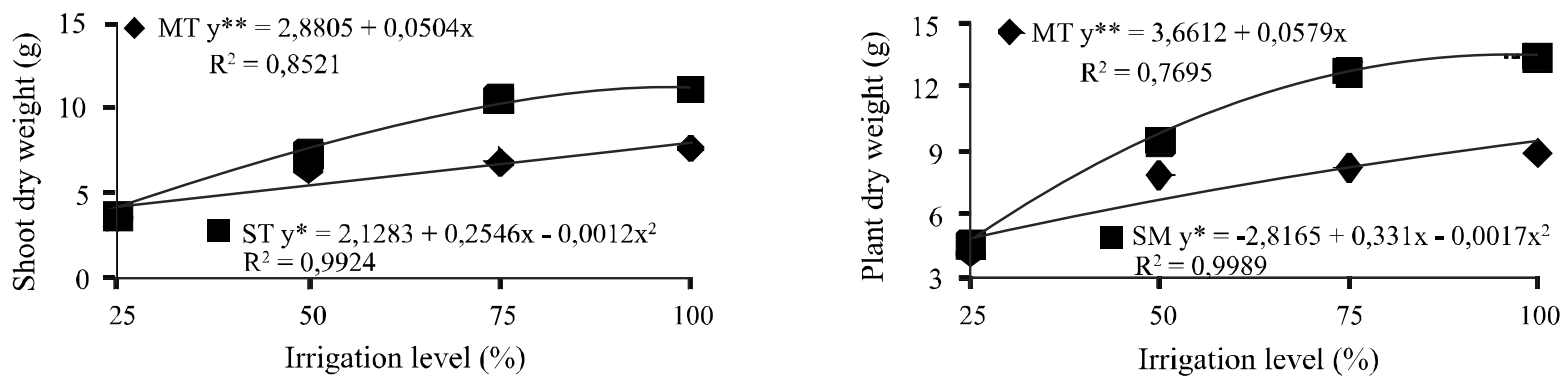

${ }^{* *}$ Significant difference by F-test at $1 \%$ probability; * Significant difference by F-test at $5 \%$ probability 
Specifically for soil type, it was found in this study that soil with medium texture tends to have higher SDW and PDW at the higher irrigation levels (75\% and 100\%). This behaviour may be attributed to the greater water retention capacity of these soils compared to sandy soils (Figure 2). Miranda and Pires (2001) show that soils with a more clayey texture have a more uniform distribution of pore size, which determines the absorption of a larger quantity of water, this being the reason for the reduction in water content caused by the increase in tension being more gradual. Thus, in soil of a medium texture the supply of water and nutrients to the plant is better, contributing to greater plant development.

In soil of a medium texture, when comparing the irrigation level of $100 \%$ with the level of $50 \%$, it was found that the SDW was $11.00 \mathrm{~g}$ and $7.21 \mathrm{~g}$ respectively, i.e. an increase of $3.79 \mathrm{~g}(52 \%)$ in SDW with the increase in irrigation. In the sandy soil, when comparing the irrigation level of $100 \%$ with that of $50 \%$, the shoot dry weight was found to be $7.56 \mathrm{~g}$ and $6.31 \mathrm{~g}$ respectively, i.e. an increase of $1.25 \mathrm{~g}(19.8 \%)$ in shoot dry weight with the increased irrigation (Figure 2). Interference in the development of the coffee plant can therefore also be attributed to the characteristic of each type of soil, as the water properties can interfere with irrigation management (BEUTLER et $a l .$, 2002). Thus, sandy soils, due to their constitution, tend to require more frequent irrigation to encourage a similar level of development in the coffee plants.

With the PDW, a trend was seen similar to the SDW as regards the type of soil (Figure 2). This trend can be explained by almost all the PDW being SDW, since the composition of PDW was extremely reduced, never reaching two grams.

Breaking down the interaction between irrigation levels and soil type (Ix S) for absolute growth rate (AGR), it was found that with irrigation at $25 \%$ the values were low, 0.031 and $0.028 \mathrm{~g} \mathrm{day}^{-1}$ for the soils of a medium and sandy texture respectively (Figure 3). The lower supply of water provided to the plants under water deficit, possibly resulted in a reduction in the photosynthetic rate, resulting in less absolute growth (DAMATTA, 2004). In the plant the water acts as a reactant in the metabolism, in the transport and translocation of solutes, in cell turgidity, the opening and closing of stomata, and penetration of the root system into the soil. A small imbalance in this flow of water can cause water deficit and the malfunction of numerous cellular processes (TAIZ; ZEIGER, 2013). Thus, with less water availability, a lower value for TGR was found at an irrigation level of $25 \%$ (Figure 3), compromising plant growth.

The AGR expresses the variation in plant growth (weight) for a given time, and the RGR is a measure of the speed with which a plant grows compared to its original size (CAIRO; OLIVEIRA; MESQUITA, 2008). Ferreira et al. (2009), when evaluating the formation of grafted coffee seedlings, found differences between cultivars in absolute growth rate and relative growth rate. However, in the present work, differences were found for AGA and AGR in a single cultivar only when increasing the irrigation levels (Figure 3).

The soil type influenced AGR with similar behaviour to that observed for the characteristics $\mathrm{PH}$, SDW and PDW. At 100\% irrigation it was found that the soil of a medium texture showed greater development $\left(0.1 \mathrm{~g} \mathrm{day}^{-1}\right)$, compared to the sandy soil $\left(0.065 \mathrm{~g} \mathrm{day}^{-1}\right)$, i.e. greater by $53.8 \%$ (Figure 3 ).

Under water deficit (25\% irrigation), a low RGR was found $\left(0.016 \mathrm{~g} \mathrm{~g}^{-1}\right.$ day $\left.^{-1}\right)$; whereas with the increase in irrigation levels, there was an increase in RGR, reaching $0.022 \mathrm{~g} \mathrm{~g}^{-1}$ day $^{-1}$ for $90 \%$ irrigation, i.e. $37.5 \%$ greater

Figure 3 - Absolute growth rate $\left(\mathrm{g} \mathrm{day}^{-1}\right)$ and relative growth rate $\left(\mathrm{g} \mathrm{g}^{-1}\right.$ day $\left.^{-1}\right)$ in the Acaiá Cerrado MG-1474 cultivar of arabica coffee, for irrigation level, in soils with a medium (SM) and sandy (AR) texture
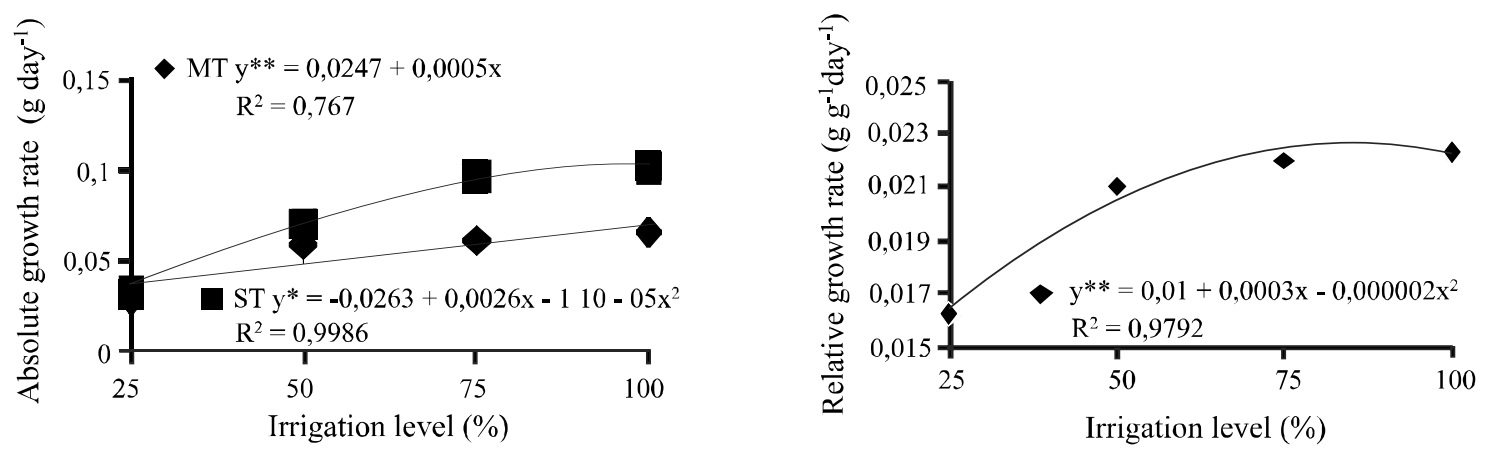

${ }^{* *}$ Significant difference by F-test at $1 \%$ probability; * Significant difference by F-test at $5 \%$ probability 
(Figure 3). Dias et al. (2005) evaluating two coffee progenies, observed a reduction in relative growth rate with an increase in water deficit.

It was found that in the case of the variables, net assimilation rate (NAR) and root dry weight (RDW), regardless of the type of soil tested, maximum growth of the plants took place at irrigation levels of $75 \%$ and $71.6 \%$ respectively; at the $100 \%$ level there was an excess of water, which possibly decreased aeration in the root system and thereby reduced the RDW (Figure 4). This increase in respiration (consumption of fixed carbon during photosynthesis) in the root system can be explained by the reduction in NAR at $100 \%$ irrigation (Figure 4 ), since NAR expresses the balance between photosynthesis and respiration (CAIRO; OLIVEIRA; MESQUITA, 2008). Martins et al. (2006), evaluating the development of coffee seedlings in 10-litre pots for 150 days, found that irrigation levels of $20 \%$ gave the smallest root dry weight, and that $80 \%$ irrigation resulted in an increase of $61,54 \%$ for this variable.

It was seen that both the low availability of water at $25 \%$ irrigation and the excess moisture at $100 \%$ irrigation compromised the root to shoot dry weight ratio (RDW $\mathrm{SH}^{-1}$ ) (Figure 5). The maximum value for $\mathrm{RDW} \mathrm{SH}^{-1}$ was found at an irrigation level of $54.16 \%$, this behaviour possibly being related to the moderate soil moisture.

When analysing the leaf area ratio (LAR) for an irrigation level of $57.42 \%$ (Figure 5), a lower value was seen, i.e. a smaller leaf area for a greater production of plant dry weight. From there, a reversal in behaviour is seen, requiring a greater leaf area to produce the same amount of photoassimilates (lesser efficiency of the photosynthetic apparatus), resulting in less accumulation of photoassimilates in the plant (PEREIRA et al., 2011).

Irrigation positively influenced leaf area (LA), number of leaves (NL) and the leaf area index (LAI) in the

Figure 4 - Net assimilation rate $\left(\mathrm{g} \mathrm{cm}^{2}\right.$ day $\left.^{-1}\right)$ and root dry weight $(\mathrm{g})$ in the Acaiá Cerrado MG-1474 cultivar of arabica coffee, for irrigation level
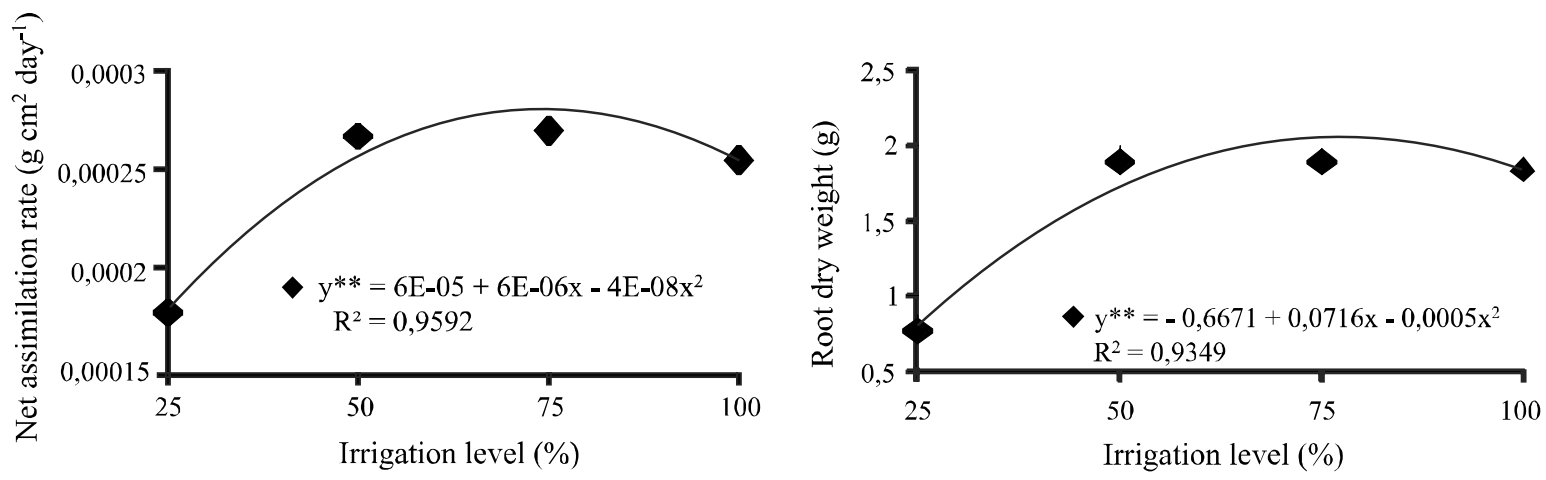

${ }^{* *}$ Significant difference by F-test at $1 \%$ probability

Figure 5 - Root dry weight to shoot dry weight ratio and leaf area ratio $\left(\mathrm{cm}^{2} \mathrm{~g}^{-1}\right)$ in the Acaiá Cerrado MG-1474 cultivar of arabica coffee, for irrigation level
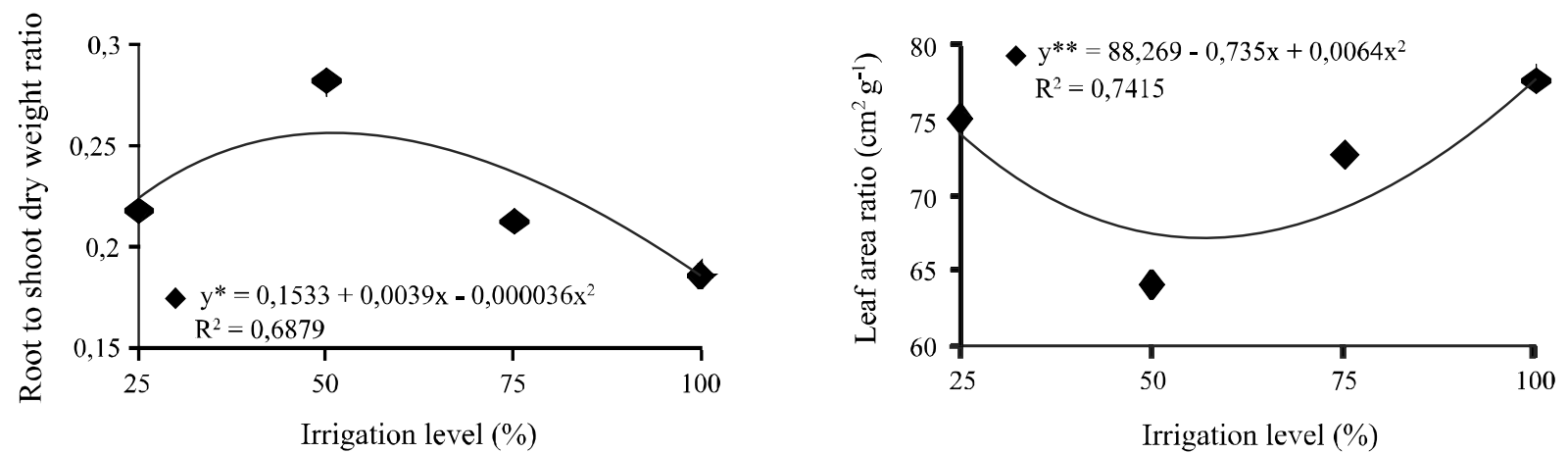

${ }^{* *}$ Significant difference by F-test at $1 \%$ probability; * Significant difference by F-test at $5 \%$ probability 
coffee plants for both soil types, which can be verified by greater growth in the plants that received the largest levels of irrigation (Figure 6). Similar behaviour was seen for leaf area by Martins et al. (2006), with maximum development at $100 \%$ irrigation. Under reduced levels of irrigation (25\%), low values for LA, NL and LAI were seen. For DaMatta (2004), one of the first responses of the plants to water deficit is a reduction in leaf area, producing smaller leaves, or even reducing the emission of new leaves.

The LA of the plants was $39.32 \%$ higher at $100 \%$ irrigation than that achieved by plants receiving only $25 \%$ irrigation (Figure 6). The increase in leaf area can be explained by the ready availability of water; this phenomenon being due to the relationship between the size reached by the leaves and the moisture in the soil (FAVARIN et al., 2002). The greater availability of water favoured a larger NL (26) when compared to irrigation at $25 \%$ (12). The larger LA with the larger NL at $100 \%$ irrigation, favoured the greater LAI, since an equal area was exploited by the plants in all treatments. Cairo, Oliveira and Mesquita (2008) pointed out that LAI is an important parameter in the analysis of the growth of a plant community, as it serves as an indicator of leaf ground cover.

The increase in irrigation to $100 \%$ gave the maximum LAI of 1.7 , i.e. $71 \%$, when compared with the lowest irrigation level of $25 \%$, with only 1.21 (Figure 6). The values for LAI in the coffee plants were higher than those found by Santana, Oliveira and Quadros (2004) of 0.737 and 0.936 at 226 and 271 days after transplanting respectively. Those authors showed that the effect of air temperature is more relevant than the water regime in determining the LAI. Thus, one hypothesis to explain the possible difference in the present work with data found in the literature, is that inside the greenhouse, temperatures were probably higher.
When carrying out the study into the use and nonuse of the water-retaining polymer, it was found that the variables, PH, SDW, PDW, AGR and RGR, showed greater development when the water-retaining polymer was used (Tables 4 and 5).

The positive effect seen with the application of the gel in the present work is related to the gradual supply of water that the water-retaining polymer provides to the plant, as well as a reduction in the leaching of nutrients, improving plant nutrition (VICHIATO; VICHIATO; SILVA, 2004). Tohidi-Moghadam et al. (2009), studying the response of rapeseed to water stress and the application of a water retaining gel, concluded that use of the gel increased the performance of the agronomic and physiological characteristics, attributing to the application of the gel the supply of water that helped photosynthesis and the levels of chlorophyll.

Oliveira et al. (2004) evaluated the influence of water retaining polymer on water retention in the soil, and found that use of the product helped increase water retention in soils of loam-clay-sand and clayey textures, increasing moisture by $41 \%$ for the loam-clay-sand soil, and $37 \%$ for the clay soil. The positive effect of the polymer was also seen by Azevedo et al. (2002), working with seedlings of arabica coffee under induced hydric deficit and with different levels of hydrated water-retaining polymer.

According to the results obtained, the action of the water-retaining polymer is similar to that of clay in the soil, albeit temporary. According to Miranda and Pires (2001), soils of a more clayey texture have a more uniform distribution of pore size, which determines the adsorption of a greater amount of water, and which is the reason that water losses are more gradual.

Similar results were found by Carvalho et al. (2009) and Carvalho et al. (2011), when evaluating doses of polymer and irrigation frequency. Those authors found

Figure 6 - Leaf area $\left(\mathrm{cm}^{2}\right)$, number of leaves, leaf area index in the Acaiá Cerrado MG-1474 cultivar of arabica coffee, for irrigation level
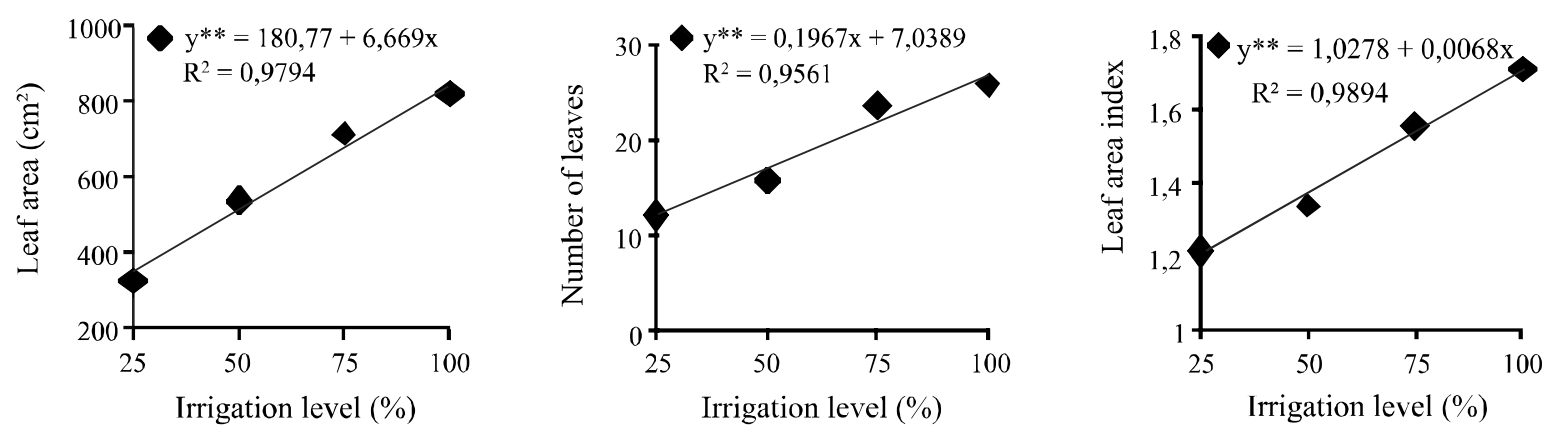

${ }^{* *}$ Significant difference by F-test at $1 \%$ probability 
Table 4 - Mean values for stem diameter (SD, mm), plant height (PH, cm), leaf area (LA, $\mathrm{cm}^{2}$ ), number of leaves (NL), shoot dry weight (SDW, g) and plant dry weight (PDW, g), in the Acaiá Cerrado MG-1474 cultivar of arabica coffee, with and without the use of a water retaining polymer

\begin{tabular}{lcccccc}
\hline \multicolumn{1}{c}{ Polymer } & SD & PH & LA & NL & SDW & PDW \\
\hline No Gel & $4.53 \mathrm{~A}$ & $32.32 \mathrm{~B}$ & $565.93 \mathrm{~A}$ & $18.54 \mathrm{~A}$ & $6.49 \mathrm{~B}$ & $7.91 \mathrm{~B}$ \\
With Gel & $4.84 \mathrm{~A}$ & $34.41 \mathrm{~A}$ & $629.24 \mathrm{~A}$ & $20.12 \mathrm{~A}$ & $7.60 \mathrm{~A}$ & $9.39 \mathrm{~A}$ \\
\hline
\end{tabular}

${ }^{*}$ Different letters in a column indicate a significant difference by F-test at $5 \%$ probability

Table 5 - Mean values for root dry weight (RDW, g), root dry weight to shoot dry weight ratio (RDW $\mathrm{SH}^{-1}$ ), leaf area ratio $\left(\mathrm{LAR}, \mathrm{cm}^{2} \mathrm{~g}^{-1}\right.$ ), absolute growth rate $\left(\mathrm{AGR}, \mathrm{g} \mathrm{day}^{-1}\right)$, relative growth rate (RGR, $\left.\mathrm{g} \mathrm{g}^{-1} \mathrm{day}^{-1}\right)$, net assimilation rate $\left(\mathrm{NAR}, \mathrm{g} \mathrm{cm}^{2}\right.$ day $^{-1}$ ) and leaf area index (LAI) in the Acaiá Cerrado MG-1474 cultivar of arabica coffee, with and without the use of a water retaining polymer

\begin{tabular}{llcccccc}
\hline \multicolumn{1}{c}{ Polymer } & RDW & RDW/SH & LAR & AGR & RGR & NAR & LAI \\
\hline No Gel & $1.41 \mathrm{~A}^{*}$ & $0.22 \mathrm{~A}$ & $74.10 \mathrm{~A}$ & $0.058 \mathrm{~B}$ & $0.019 \mathrm{~B}$ & $0.00023 \mathrm{~A}$ & $1.43 \mathrm{~A}$ \\
With Gel & $1.79 \mathrm{~A}$ & $0.23 \mathrm{~A}$ & $70.64 \mathrm{~A}$ & $0.070 \mathrm{~A}$ & $0.021 \mathrm{~A}$ & $0.00025 \mathrm{~A}$ & $1.48 \mathrm{~A}$ \\
\hline
\end{tabular}

${ }^{*}$ Different letters in a column indicate a significant difference by F-test at $5 \%$ probability

that the application of doses of polymer benefits the growth of coffee seedlings, resulting in greater stem diameter, plant height and leaf area, as well as greater gains in dry weight (roots and shoots). Marques; Cripa and Martinez (2013), evaluating water retaining polymer as a substitute for supplemental irrigation in coffee seedlings, found that the polymer resulted in seedlings of the same quality as the irrigated seedlings.

The water retaining polymer increased the supply of water to the plants, releasing moisture more gradually into the soil, which may prove to be an alternative to optimising the irrigation water, especially in soils of a sandy texture.

\section{CONCLUSIONS}

1. Irrigation promotes greater growth in coffee plants in soils of a medium texture compared to sandy soils;

2. The use of hydrated water retaining polymer when planting coffee seedlings, promotes greater plant growth.

\section{ACKNOWLEDGEMENTS}

The authors wish to thank Fapemig for the scholarships. Thanks are also due to UFLA (Sector for Coffee Cultivation) for their support in conducting the experiment.
This work was carried out with the support of $\mathrm{CNPq}$, the National Council for Scientific and Technological Development, Brazil.

\section{REFERENCES}

ALMEIDA, L. S. et al. Crescimento de mudas de Jacaranda puberula Cham. em viveiro, submetidas a diferentes níveis de luminosidade. Ciência Florestal, v. 15 n. 3, p. 323-329, jul./set. 2005.

AZEVEDO, T. L. F. et al. Níveis de polímero superabsorvente, frequências de irrigação e crescimento de mudas de café. Acta Scientiarum, v. 24, n. 5, p. 1239-1243, 2002.

BEUTLER, A. N. et al. Retenção de água em dois tipos de Latossolo sob diferentes usos. Revista Brasileira de Ciência do Solo, v. 26, n. 3, p. 829-834, maio/jun. 2002.

CAIRO, P. A. R.; OLIVEIRA, L. E. M.; MESQUITA, A. C. Análise de crescimento de plantas. Vitória da Conquista: Edições UESB, 2008. 72 p.

CARVALHO, A. D. et al. Correlação entre crescimento e produtividade de cultivares de café em diferentes regiões de Minas Gerais, Brasil. Pesquisa Agropecuária Brasileira, v. 45, n. 3, p. 269-275, mar. 2010.

CARVAlho, J. A. et al. Desenvolvimento de mudas de cafeeiro com diferentes doses de polímero hidro retentor e turnos de rega. In: SIMPÓSIO DE PESQUISA DOS CAFÉS DO BRASIL, 6., 2009, Vitória. Anais eletrônicos... Brasília: EMBRAPA Café, 2009. Disponível em: <http://www.sbicafe. ufv.br/handle/10820/3508>. Acesso em: 22 jul 2013. 
CARVALHO, J. A. et al. Utilização de polímero hidrorretentor no plantio de mudas de cafeeiro. Engenharia na Agricultura, v. 19, n. 2, p. 164-171. 2011.

CLEMENTE, F. M. V. T. et al. Faixas críticas de teores foliares de macronutrientes no cafeeiro em pós-plantioprimeiro ano. Coffee Science, v. 3, n. 1, p. 47-57, jan./jun. 2008.

DAMATTA, F. M. Exploring drought tolerance in coffee: a physiological approach with some insights for plant breeding. Brazilian Journal of Plant Physiology, v. 16, n. 1, p. 1-6, jan./ abr. 2004

DANTAS, A. A. A.; CARVALHO, L. G.; FERREIRA, E. Classificação e tendências climáticas em Lavras, MG. Ciência e Agrotecnologia, v. 31, n. 6, p. 1862-1866, nov./ dez. 2007.

DIAS, P. C. et al. Crescimento e alocação de biomassa em duas progênies de café submetidas a déficit hídrico moderado. In: SIMPÓSIO DE PESQUISA DOS CAFÉS DO BRASIL, 4., 2005, Londrina. Anais... Brasília: Embrapa Café, 2005. $1 \mathrm{CD}-\mathrm{ROM}$.

FAQUIN, V.; VALE, F. R.; FURTINI NETO, A. E. Cultivo de plantas em ambiente controlado: solução nutritiva, hidroponia e em vasos com solo. Lavras, MG: UFLA, 2008. $18 \mathrm{p}$.

FAVARIN, J. L. et al. Equações para a estimativa do índice de área foliar do cafeeiro. Pesquisa Agropecuária Brasileira, v. 37, n. 6, p. 769-773, jun. 2002.

FERREIRA, A. D. et al. Índices fisiológicos de mudas de Coffea arabica L. enxertadas sobre Coffea canephora. Coffee Science, v. 4, n. 1, p. 35-40, jan./jun. 2009.

FERREIRA, D. F. Sisvar: a computer statistical analysis system. Ciência e Agrotecnologia, v. 35, n. 6, p. 1039-1042, nov./dez. 2011.

FONTES, P. C. R.; DIAS, E. N.; SILVA, D. J. H. Dinâmica do crescimento, distribuição de matéria seca na planta e produção de pimentão em ambiente protegido. Horticultura Brasileira, v. 23, n. 1, p. 94-99, jan./mar. 2005.

GOMES, J. B. V. et al. Análise de componentes principais de atributos físicos, químicos e mineralógicos de solos do bioma cerrado. Revista Brasileira de Ciência do Solo, v. 28, n. 1, p. 137-153, jan./fev. 2004.
MARQUES, P. A. A.; CRIPA, M. A. M.; MARTINEZ, E. H. Hidrogel como substituto da irrigação complementar em viveiro telado de mudas de cafeeiro. Ciência Rural, v. 43, n. 1, p. 1-7, 2013.

MARTINS, C. C. et al. Crescimento inicial do café Conilon (Coffea canephora Pierre ex Froehner) sob diferentes lâminas de irrigação. Engenharia na Agricultura, v. 14, n. 3, p. 193-201, jul./set. 2006

MIRANDA, J. H.; PIRES, R. C. M. Irrigação. Piracicaba: FUNEP, 2001. 410 p. (Série Engenharia, 1).

OLIVEIRA, R. A. et al. Influência de um polímero hidroabsorvente sobre a retenção de água no solo. Revista Brasileira de Engenharia Agrícola e Ambiental, v. 8, n. 1, p. 160-163, jan./jun. 2004.

PEREIRA, S. P. et al. Crescimento, produtividade e bienalidade do cafeeiro em função do espaçamento de cultivo. Pesquisa Agropecuária Brasileira, v. 46, n. 2, p. 152-160, fev. 2011.

PIEVE, L. M. et al. Uso de polímero hidro retentor na implantação de lavouras cafeeiras. Coffee Science, v. 8, n. 3, p. 314-323, jul./ set. 2013.

SANTANA, M. S.; OLIVEIRA, C. A. S.; QUADROS, M. Crescimento de duas cultivares de cafeeiro adensado influenciado por níveis de irrigação localizada. Engenharia Agrícola, v. 24, n. 3, p. 644-653, set./dez. 2004.

SANTOS, H. G. dos. Sistema brasileiro de classificação de solos. 3. ed. Brasília: Embrapa, 2013. 353 p.

TAIZ, L.; ZEIGER, E. Fisiologia vegetal. 5. ed. Porto Alegre: Artmed, 2013. 918 p.

TOHIDI-MOGHADAM, H. R. et al. Response of six oilseed rape genotypes to water stress and hydrogel application. Pesquisa Agropecuária Tropical, v. 39, n. 3, p. 243-250, jul./set. 2009.

VICHIATO, M.; VICHIATO, M. R. M.; SILVA, C. R. R. Crescimento e composição mineral do porta-enxerto tangerineira 'Cleópatra' cultivado em substrato acrescido de polímero hidrorretentor. Ciência e Agrotecnologia, v. 28, n. 4, p. 748-756, jul./ago. 2004.

ZONTA, J. H. et al. Influência de diferentes turnos de rega e doses de hidroabsorvente no desenvolvimento inicial da cultura do café conillon (Coffea canephora Pierre). Idesia, v. 27 , n. 3, p. 29-34, set./dez. 2009. 